\title{
Molecular genetic analysis and phenology of the plane lace bug Corythucha ciliata Say (Hemiptera: Tingidae) in different parts of Krasnodar Krai
}

\author{
Ekaterina Besedina $^{1}{ }^{*}$, Vladimir Kil $^{2}$, Vladimir Ismailov $^{1}$, and Maria Karpunina ${ }^{2}$ \\ ${ }^{1}$ All-Russian Research Institute of Biological Plant Protection, p/o 39, Krasnodar, 350039, Russia \\ ${ }^{2}$ Kuban State University, 149 Stavropolskaya st., Krasnodar, 350058, Russia
}

\begin{abstract}
The article presents the results of studying the phenology and dynamics of the number of plane lace bug Corythucha ciliata Say. RAPD analysis of geographic populations of plane lace bug from various parts of Krasnodar Krai revealed a high level of DNA polymorphism, genetic diversity, genetic similarity and the absence of significant differences between the samples for these indicators. It shows that the majority of the genetic variation $(90.2 \%)$ is intrapopulation, while the interpopulation variation accounts for $9.8 \%$ of the total. A significant drift of genes was revealed between the populations of $C$. ciliata $(\mathrm{Nm}=4.56)$ and a high degree of genetic similarity between them at the intraspecific level. The analyzed insect samples are concluded to be subpopulations of one plane lace bug population.
\end{abstract}

\section{Introduction}

Invasions of adventitious pests are a great problem of our time caused by globalization processes leading to wide transport communication between continents, states and regions. The study of alien insect species becomes a matter of environmental and economic security of countries, because many of them cause huge damage to agriculture and forestry, destroy local ecosystems [1]. Sometimes the invasion of adventive species has the character of emergency situations - the so-called "entomogenic catastrophes", a striking example of which are the invasions of lace bugs $[2,3]$.

The plane lace bug (Corythucha ciliata Say) is a natural inhabitant of North America. From North America, the bug entered Europe and was first registered in Italy in 1966. Then the species spread to other European countries: Croatia, Slovenia (1972), South of France (1975), Hungary (1976) South Austria (1983), Switzerland (1983), the former Czechoslovak Republic (1986), Bulgaria (1986), Greece (1988) [4]. In 2002, an invasive pest was first detected in China, in the Hunan province, afterwards it spread to 11 provinces

*Corresponding author: katrina7283@yandex.ru 
and concentrated along the Yangtze River basin [5]. In 2014 the bug colonies were found on plane trees in the Republic of South Africa (Cape Town) [6].

In Russia, C. ciliata was first registered in 1999 in the city of Krasnodar on the crown of a plane tree (Platanus) [7] and currently covers the western, central parts and almost the entire Black Sea coast of Krasnodar Krai [8]. In 2017, this pest was classified by the Eurasian Economic Union as a quarantine insect species [9].

The adults and nymphs of the plane lace bug, which are observed throughout the growing season (March-November), severely damage the crowns of plane trees, significantly reduce photosynthesis and weaken the trees [8]. As a result of severe damage caused by plane lace bugs, there is not only a sharp weakening of tree stands, but also favorable conditions are created for the development of diseases that can cause their death. Despite the widespreading and invasive style of the lace bug development, the specific features of population genetics, biology, and harmfulness have been poorly studied $[10,11]$.

Successful implementation of programs for controlling the number of harmful arthropods requires knowledge of the phenology, dynamics of the number and genetics of pest populations. This includes knowledge of the genetic structure of populations, migration processes, conditions of acclimatization, ethology, reproductive abilities and trophic relationships of the studied species. The results of monitoring lace bugs using molecular genetic methods will allow us to assess the variability of the genetic structure of invasive pest populations and intraspecific genetic diversity, which will make it possible to conclude about their further spreading and harmfulness under new conditions [12]. Some publications cover the data on the study of the genetic structure and diversity of Asian and European populations of plane lace bugs using analysis of mitochondrial DNA and microsatellites. The use of these genetic markers made it possible to determine the influence of the environment on the migration and invasive processes of this pest [13].

The aim of this research was to study some issues of phenology, biological features, and divergence of $C$. ciliata species, which is widespread in the South of Russia on the basis of phytosanitary monitoring and analysis of the variability of the molecular genetic structure and genetic similarity of various geographical samples from the plane lace bug population in Krasnodar Krai.

\section{Material and methods}

The the field studies were carried out in the plane-tree alleys of the FSBSI ARRIBPP (Krasnodar). Phenological observations and counting of the number of C. ciliata bugs started from the moment of emergence of overwintered insects. The experiments were carried out on model trees of the eastern plane tree (Platanus orientalis L.). Pest counts were carried out every 7-10 days during the entire growing season, until adult insects went wintering.

The molecular genetic studies were carried out on the insect samples $(n=20)$ from the natural plane lace bug C. ciliata populations of Krasnodar Krai (Krasnodar, Kropotkin and Lazarevskoye). Isolation of DNA from insect individuals (adults), amplification, and electrophoresis were carried out according to our previously developed technique $[14,15]$. DNA polymorphism of the studied samples from the bug populations was assessed using two highly specific for the plane lace bug DNA primers: ORA09, ORA18 $[16,17]$. The primers were synthesized by «Eurogen» company (Moscow), DNA polymerase, buffer and other necessary components for PCR were supplied by «Sibenzim» company Moscow).

Genetic diversity, genetic similarity of populations and cluster analysis of data were determined using Nei and Shennon, from the software package POPGENE version 1.31. A comparative assessment of the average values for the samples was carried out according to the Student criterion using the Excell program. 


\section{Results and discussion}

As a result of the studies, the biological and phenological features of the plane lace bug were studied in the central zone of Krasnodar Krai in 2018-2019. During the observation period, all the development stages of the plane lace bug (adult-egg-larvae of all ages) were identified. It was found that after wintering, single insects emerged on the surface of trees in early March, and a mass outcome was noted in the II-III decades of April when young leaves appeared. After 8-14 days. after the start of feeding, copulation of bugs was recorded, and after 5-7 days. after copulation, the females began to lay eggs. Hatching of larvae was observed from the second decade of May. The peak number of larvae (57 ind./leaf) in 2018 was in the II-III decade of July. The peak number of adults (48 ind./leaf) in 2018 was in the second decade of August (Figure 1). Larvae were detected before the II - III decades of October. Single adults were observed until the first decade of November.

In 2019, the overwintered bugs appeared in the third decade of March and the first oviposition was observed at the end of May. In the $1^{\text {st }}$ decade of June, hatching of larvae was noted on the experimental plot on the plane trees; in the $2^{\text {nd }}$ decade of June, the number of Corythucha ciliata bugs began to gradually increase. The peak number of larvae (44 ind./leaf) in 2019 was in the third decade of July, and the peak number of adults (32 ind./leaf) was in the second decade of August (Figure 1).

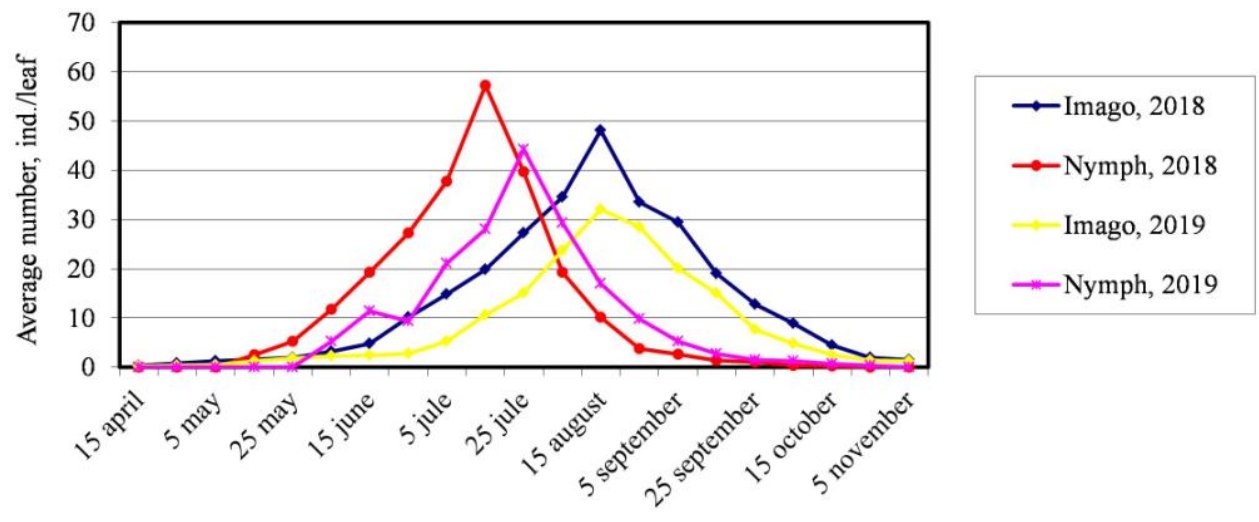

Records dates

Fig. 1. The dynamics of the number of plane lace bugs (Krasnodar, 2018-2019)

A few publications on the molecular genetic analysis of plane lace lbug populations in China and Europe determine a great interest in conducting similar studies for populations acclimatized in Russia, in Krasnodar Krai in particular. A detailed genetic analysis of the variability of the genetic structure with an assessment of the genetic similarities of the geographic populations of the plane lace mice bug in Krasnodar Krai, depending on environmental conditions, is not only of scientific interest, but also has practical value, helping, for example, to track the distribution of the species.

Based on the results of the RAPD-PCR analysis, we assessed the variability of the structure of plane lace bug geographical subpopulations from different parts of Krasnodar Krai (Figure 2). 


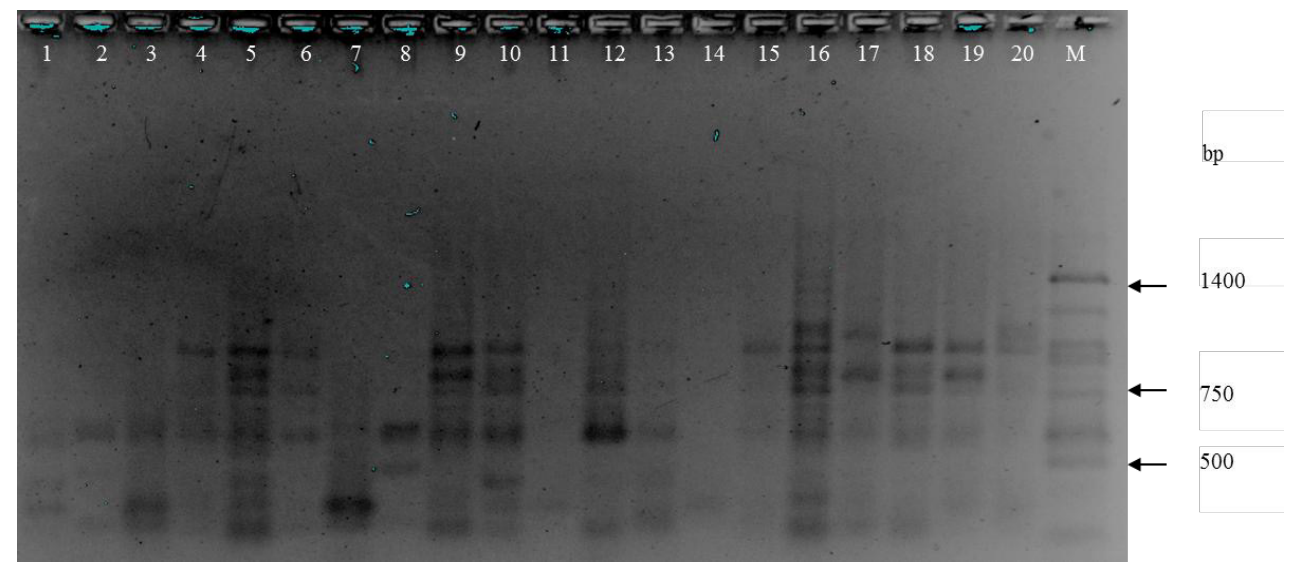

Tracks: 1-7 - Kropotkin subpopulation;

8-14 - Krasnodar subpopulation;

15-20 - Lazarevskaya subpopulation;

M - molecular weight marker (GeneRuler 100 bp Plus DNA Ladder by "Fermentas", Lithuania)

Fig. 2. Electrophoregrams of the DNA amplification products of the plane lace bug C. ciliata subpopulation in $1.8 \%$ agarose with the RAPD primer OPA09

Molecular genetic analysis of $C$. ciliata revealed a generally high level of DNA polymorphism $(\mathrm{Pt}=100.0 \%)$ and genetic diversity $(\mathrm{H}=0.29-0.34)$ in the population and the absence of differences between the samples for these indicators (Table 1,2).

Table 1. DNA polymorphism and genetic diversity of C. ciliata subpopulations in two primers (17 RAPD loci)

\begin{tabular}{|c|c|c|c|c|c|}
\hline Subpopulation & $\mathrm{P}(\%)$ & $\mathrm{Na} \pm \mathrm{SD}^{*}$ & $\mathrm{Ne} \pm \mathrm{SD}^{*}$ & $\mathrm{H} \pm \mathrm{SD}^{*}$ & $\mathrm{I} \pm \mathrm{SD}^{*}$ \\
\hline Krasnodar & 94.10 & $1.94 \pm 0.24$ & $1.48 \pm 0.33$ & $0.29 \pm 0.16$ & $0.44 \pm 0.21$ \\
\hline Kropotkin & 100.00 & $2.00 \pm 0.00$ & $1.58 \pm 0.32$ & $0.34 \pm 0.15$ & $0.50 \pm 0.19$ \\
\hline Lazarevskaya & 100.00 & $2.00 \pm 0.00$ & $1.58 \pm 0.32$ & $0.34 \pm 0.15$ & $0.51 \pm 0.17$ \\
\hline \multicolumn{6}{|c|}{$\begin{array}{l}* \mathrm{t}_{\text {факт }} \leq \mathrm{t}_{05}-\text { differences are not significant; } \\
\mathrm{P}-\% \text { polymorphic loci in a subpopulation (including zero loci); } \\
\mathrm{Na}-\text { the number of alleles per locus; } \\
\mathrm{Ne} \text { - effective number of alleles per locus; } \\
\mathrm{H} \text { - genetic diversity by Nei (1973); } \\
\mathrm{I} \text { - Shannon information index; } \\
\pm \mathrm{SD} \text { - standard deviation }\end{array}$} \\
\hline
\end{tabular}

Table 2. Total genetic variability of the C. ciliata population at all RAPD loci $(\mathrm{n}=17)$

\begin{tabular}{|c|c|c|c|c|c|c|c|}
\hline Indicator & $\mathrm{Pt}(\%)$ & $\mathrm{Na}$ & $\mathrm{Ne}$ & $\mathrm{Ht}$ & Hs & Gst & $\mathrm{Nm}$ \\
\hline Value $( \pm \mathrm{SD})$ & 100.00 & $2.00 \pm 0.00$ & $1.63 \pm 0.32$ & $0.36 \pm 0.02$ & $0.32 \pm 0.02$ & 0.09 & 4.56 \\
\hline $\begin{array}{l}\mathrm{Pt}-\% \text { polymor } \\
\mathrm{Na} \text { - the numbe } \\
\mathrm{Ne} \text { - effective } \\
\mathrm{Ht} \text { - total genet } \\
\mathrm{Hs} \text { - average ge } \\
\mathrm{Gst} \text { - genetic di } \\
\mathrm{Nm} \text { - indicator }\end{array}$ & $\begin{array}{l}\text { ic loci in } \\
\text { of alleles } \\
\text { mber of a } \\
\text { diversity } \\
\text { etic diver } \\
\text { erentiatio } \\
\text { f gene flo }\end{array}$ & $\begin{array}{l}11 \text { samples; } \\
\text { er locus; } \\
\text { eles per locu } \\
\text { n a populatio } \\
\text { ty within the } \\
\text { coefficient } b \\
\text { between po }\end{array}$ & $\begin{array}{l}\text { by Nei; } \\
\text { ubpopulatio } \\
\text { Nei (1987); } \\
\text { lations }\end{array}$ & by Nei; & & & \\
\hline
\end{tabular}


In turn, the analysis of genetic differences between the studied samples of insects also revealed a high degree of similarity between them (genetic identity $(\mathrm{GI})=0.909-0.948$ ) (Table 3).

The closest in genetic terms were the Kropotkin and Lazarevskaya subpopulations (GI = 0.948 , genetic distance $(\mathrm{GD})=0.053)$. This was also demonstrated by cluster analysis of data, where these two samples from the bug population stood separately and formed one cluster (Figure 3). At the same time, the samples from Krasnodar and Lazarevskaya subpopulations were somewhat more different from the others $(\mathrm{GD}=0.096)$. Perhaps this is due to the large geographical distance between them.

Table 3. Genetic distances (GD) (below the diagonal) and genetic identity (GI) (above the diagonal) between subpopulations of $C$. ciliata

\begin{tabular}{|l|c|c|c|}
\hline \multicolumn{1}{|c|}{ Subpopulation } & Kropotkin & Krasnodar & Lazarevskaya \\
\hline Kropotkin & - & 0.943 & 0.948 \\
\hline Krasnodar & 0.059 & - & 0.909 \\
\hline Lazarevskaya & 0.053 & 0.096 & - \\
\hline
\end{tabular}

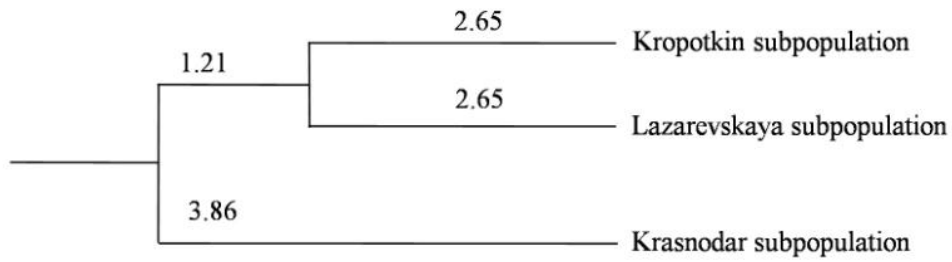

Fig. 3. Dendrogram of genetic distances between clusters of $C$. ciliata subpopulations

It is important to note that all the studied samples were characterized by a high degree of genetic similarity. Moreover, a high degree of genetic diversity and the absence of differences between the samples on this indicator show a significant level of genetic drift between the studied populations. These data suggest that the studied geographical samples of $C$. ciliata insects are subpopulations of one population at an early stage of species divergence in southern Russia.

This conclusion is also proved by the fact that genetic diversity (according to Nei) within geographical samples $(\mathrm{Hs}=0.32$ ) amounted up to $90.2 \%$ of the total genetic diversity in the bug population $(\mathrm{Ht}=0.36)$. The revealed correlation of intra- and interpopulation variability, estimated by the Shannon index (I), showed similar data. This indicated a significant level of gene flow between subpopulations, which is also confirmed by the calculated data: the estimate of the genetic flow level between subpopulations was $\mathrm{Nm}=4.56$, and the genetic differentiation coefficient Gst $=0.09$ (Table 3).

Such level of gene drift is a significant obstacle to differentiation of subpopulations and is a determining factor affecting the genetic structure of a population. The relatively low Gst value is confirmed by the fact that only $9.8 \%$ of the total genetic variation of a population falls on the fraction of variation between subpopulations, which determines the differentiation between samples.

Thus, the molecular genetic analysis revealed a high level of DNA polymorphism and intrapopulation genetic diversity of $C$. ciliata. Most of the genetic variation is composed of intrapopulation variation $(90.2 \%$ ), while the share of interpopulation variation remains $9.8 \%$ of the total variation. A significant level of gene flow was revealed between plane lace bug subpopulations. All the analyzed insect samples are likely to be subpopulations of one 
plane lace bug population, which are in the process of divergence of the species in the South of Russia.

Studies on the phenology, harmfulness and dynamics of the number of insects were carried out in accordance with the State assignment No. 075-00376-19-00 of the Ministry of Science and Higher Education of the Russian Federation as a part of the research on the topic No. 0686-2019-0012.

Molecular genetic studies of the geographic plane lace bug populations were supported by the Grant No. 19-44-233009 r_mol_a of the Russian Foundation for Basic Research and the Administration of Krasnodar Krai.

\section{References}

1. V.Yu. Maslyakov, S.S. Izhevsky, Invasions of herbivorous insects in the European part of Russia. 289 (2011) https://www.zin.ru/ANIMALIA/COLEOPTERA/pdf/Maslyakov_Izhevsky_2011_Insects_i nvasion.pdf

2. M.G. Volkovich, E.G. Mozolevskaya, Bulletin of the St. Petersburg Forestry Academy. 207, 8-19 (2014) https://www.elibrary.ru/download/elibrary 22800579 92519357.pdf

3. Yu. Yu. Dgebuadze, V.G. Petrosyan, L.A. Khlyap, The most dangerous invasive species of Russia (TOP-100). 688 (2018) http://www.sevin.ru/top100worst/TOP_100_PrintVersion.pdf

4. L. Hufnagel, M. Ladanyl, B. Oszi, Applied ecology and environmental research. 4(1) 135-150 (2005) http://aloki.hu/pdf/0401 135150.pdf

5. J. Ruiting, L. Bo, Biodiversity Science. 18(6), 638-646 (2010) https://doi.org/10.3724/sp.j.1003.2010.638

6. M.D. Picker, C.L. Griffiths, African Entomology. 23(1), 247-249 (2015) https://doi.org/10.4001/003.023.0125

7. K. Voigt, Zoosystematica Rossica. 10(1), 76 (2001) https://www.zin.ru/Journals/zsr/content/2001/zr_2001_10_1_Voigt.pdf

8. V.I. Schurov, A.G. Rakov, Bulletin of the St. Petersburg Forestry Academy. 196, 287-294 (2011) https://www.elibrary.ru/download/elibrary 20370784 16172616.pdf

9. https://gd.eppo.int/taxon/CRTHCI

10. W.-Ya. Yang, W.-W. Yu, Yu.-Zh. Du, Gene. 27(401), 27-40 (2013) https://doi.org/10.1016/j.gene.2013.08.087

11. F. Li, R. Wang, C. Qu, N. Fu, Plos one. 11(8), 1-19 (2016) https://www.researchgate.net/profile/Ran_Wang6/publication/305926171_Sequencing_and Characterization of the Invasive Sycamore Lace_Bug_Corythucha_ciliata_Hemiptera Tingidae Transcriptome/links/57a84cdf08ae $7 \overline{\mathrm{e}} 6 \mathrm{e} 131 \mathrm{fb} 18 /$ Sequencing-andCharacterization-of-the-Invasive-Sycamore-Lace-Bug-Corythucha-ciliata-HemipteraTingidae-Transcriptome.pdf

12. A.D. Roe, A.S. Torson, G. Bilodeau, P. Bilodeau, G.S. Blackburn, M. Cui, M. Cusson, D. Doucet, V.C. Griess, V. Lafond, G. Paradis, I. Porth, J. Prunier, V. Srivastava, E. Tremblay, A. Uzunovic, D. Yemshanov, C. Hamelin, Journal of Pest Science. 92, 51-70 (2019) https://elib.pstu.ru/EdsRecord/a9h,134561593\#html

13. W.-Ya. Yang, X.-T. Tang, R.-T. Ju, Yo.-Zh. \& Yu. Du, Scientific Reports. 7, 635 (2017) https://www.ncbi.nlm.nih.gov/pmc/articles/PMC5428010/

14. V.I. Kil, E.N. Besedina, I.S. Tsygikalo, Reports of the RAAS. 5, 29-33 (2015) https://elib.pstu.ru/vufind/EdsRecord/edselr,edselr.24112932

15. V.I. Kil, Agri Res \& Tech: Open Access J., 9(4), 555769 (2017) https://doi.org/10.19080/ARTOAJ.2017.09.555769 
16. V.I. Kil, Reports of the RAASB. 6, 21-24 (2014)

https://www.elibrary.ru/download/elibrary_22448347_50537850.pdf

17. E.N. Besedina, V.I. Kil, Gardening and Viticulture. 6, 21-25 (2019)

https://www.sadivin.com/jour/article/view/404 